\title{
Variability of winter and summer surface ozone in Mexico City on the intraseasonal timescale
}

\author{
Bradford S. Barrett ${ }^{1,2}$ and Graciela B. Raga ${ }^{1}$ \\ ${ }^{1}$ Centro de Ciencias de la Atmósfera, Universidad Nacional Autónoma de México, Mexico City 04510, Mexico \\ ${ }^{2}$ Oceanography Department, US Naval Academy, Annapolis, MD 21401, USA \\ Correspondence to: Graciela B. Raga (raga.graciela@gmail.com,raga@unam.mx)
}

Received: 23 June 2016 - Published in Atmos. Chem. Phys. Discuss.: 2 September 2016

Revised: 5 November 2016 - Accepted: 21 November 2016 - Published: 12 December 2016

\begin{abstract}
Surface ozone concentrations in Mexico City frequently exceed the Mexican standard and have proven difficult to forecast due to changes in meteorological conditions at its tropical location. The Madden-Julian Oscillation (MJO) is largely responsible for intraseasonal variability in the tropics. Circulation patterns in the lower and upper troposphere and precipitation are associated with the oscillation as it progresses eastward around the planet. It is typically described by phases (labeled 1 through 8 ), which correspond to the broad longitudinal location of the active component of the oscillation with enhanced precipitation. In this study we evaluate the intraseasonal variability of winter and summer surface ozone concentrations in Mexico City, which was investigated over the period 1986-2014 to determine if there is a modulation by the MJO that would aid in the forecast of high-pollution episodes.

Over 1000000 hourly observations of surface ozone from five stations around the metropolitan area were standardized and then binned by active phase of the MJO, with phase determined using the real-time multivariate MJO index. Highest winter ozone concentrations were found in Mexico City on days when the MJO was active and in phase 2 (over the Indian Ocean), and highest summer ozone concentrations were found on days when the MJO was active and in phase 6 (over the western Pacific Ocean). Lowest winter ozone concentrations were found during active MJO phase 8 (over the eastern Pacific Ocean), and lowest summer ozone concentrations were found during active MJO phase 1 (over the Atlantic Ocean). Anomalies of reanalysis-based cloud cover and UV-B radiation supported the observed variability in surface ozone in both summer and winter: MJO phases with highest ozone concentration had largest positive UV-B
\end{abstract}

radiation anomalies and lowest cloud-cover fraction, while phases with lowest ozone concentration had largest negative UV-B radiation anomalies and highest cloud-cover fraction. Furthermore, geopotential height anomalies at $250 \mathrm{hPa}$ favoring reduced cloudiness, and thus elevated surface ozone, were found in both seasons during MJO phases with abovenormal ozone concentrations. Similar height anomalies at $250 \mathrm{hPa}$ favoring enhanced cloudiness, and thus reduced surface ozone, were found in both seasons during MJO phases with below-normal ozone concentrations. These anomalies confirm a physical pathway for MJO modulation of surface ozone via modulation of the upper troposphere.

\section{Introduction}

Ozone is hazardous to human health (WHO, 2008) and is an ubiquitous problem in many megacities around the world. Tropospheric ozone is a secondary pollutant produced by complex photochemistry from anthropogenic emissions, and high ozone events typically affect mid-latitude urban areas during summer, while in the tropics, such events can be observed throughout the year. The problem of the incidence of high surface ozone events is exacerbated in Mexico City, a megacity with 21 million inhabitants, because of the intense solar radiation received at its relatively high elevation (more than $2200 \mathrm{~m}$ above sea level) and tropical latitude $\left(19.4^{\circ} \mathrm{N}\right)$ (Lei et al., 2007). Furthermore, the city is located in a basin, effectively preventing efficient ventilation of the polluted air (Fast and Zhong, 1998; Whiteman et al., 2000; Zhang et al., 2009). 
Seasonal variability in maximum surface ozone concentrations is not large in Mexico City due to its geographical location (Raga and LeMoyne, 1996). Both in the dry winter (December-February) and wet summer (June-August) months, clear skies and strong insolation in the morning hours promote rapid generation of surface ozone via photochemical conversions from anthropogenic precursor emissions near the surface. In both seasons, as the day progresses, the boundary layer becomes unstable from solar radiation and deepens, diluting pollutant concentrations near the surface. The growth of the boundary layer in Mexico City occurs over the course of a few hours, with typical heights reaching at least $1.2 \mathrm{~km}$ above the surface (Nickerson et al., 1992; Perez Vidal and Raga, 1998), even during the winter months when insolation is reduced at this latitude. Highest ozone concentrations during the winter months are often seen on days with strong insolation and light or no surface wind (Lei et al., 2007). In summer months, clouds and precipitation generally reduce the number of days with extremely elevated surface ozone concentrations. However, when large-scale atmospheric conditions are favorable, such as when a highpressure regime and associated clear skies affect the Mexico City basin, elevated concentrations of surface ozone are also recorded in summer (Raga and Le Moyne, 1996). Hourly surface ozone concentrations routinely exceed the national standard, set at $110 \mathrm{ppb}$ in 1993 (by law NOM-020-SSA1-1993) and modified in 2014 to 95 ppb (by law NOM-020-SSA12014). In 2015, hourly maximum $\mathrm{O}_{3}$ concentrations in every month of the year exceeded the standard set in 2014 at monitoring stations in all five geographic regions: NE, NW, SE, SW and Center (Rodríguez et al., 2016).

The problem of air quality in Mexico City has been the subject of numerous field programs over the years, typically limited in time but more comprehensive in terms of the number of parameters measured. One such campaign was MILAGRO (Megacity Initiative: Local and Global Research Observations), a very large international field campaign that took place in March 2006. The results of the large number of publications from that project are summarized by Molina et al. (2010). These results provided new insight into several processes related with pollutant transformations and chemical pathways, emerging from the analysis of the data collected with the large suite of sophisticated instrumentation deployed and the modeling performed. However, intensive field campaigns limited to 1 month, cannot address the seasonal and intraseasonal variability of the high surface ozone within the city. Past studies have examined the variability of surface ozone in Mexico City at different timescales, e.g., hourly (Raga and Le Moyne, 1996; Huerta et al., 2004; Lei et al., 2007), daily (Fast and Zhong, 1998), weekly (Stephens et al., 2008), monthly (Rodríguez et al., 2016), and seasonal (Thompson et al., 2008). All of these studies noted a primary relationship between ozone concentration in Mexico City and ultraviolet (UV) radiation, where days with more UV radiation were associated with elevated surface ozone con- centrations. Furthermore, UV radiation received at the surface is strongly modulated by cloud cover (El-Nouby Adam and Ahmed, 2016). However, as yet, no study has explored surface ozone variability in Mexico City on the intraseasonal (30-60 day) timescale, despite known relationships between the leading mode of atmospheric intraseasonal variability, the Madden-Julian Oscillation (MJO; Madden and Julian, 1971), and tropical cloud cover (Riley et al., 2011) and circulation (Madden and Julian, 1972; Zhang, 2005). The MJO is largely responsible for intraseasonal variability in the tropics. Circulation patterns in the lower and upper troposphere and precipitation are associated with the oscillation as it progresses eastward around the planet. It is typically described by phases (labeled 1 through 8), which correspond to the broad longitudinal location of the active component of the oscillation with enhanced precipitation.

In this study we evaluate the intraseasonal variability of winter and summer surface ozone concentrations in Mexico City over the period 1986-2014 to determine if there is a modulation by the MJO that would aid in the forecast of high-pollution episodes. Based on the relationships between surface ozone and UV radiation, UV radiation and cloud cover, and cloud cover and the MJO, the primary hypothesis tested in this study was the following: surface ozone varies intraseasonally by phase of the MJO.

The physical pathway hypothesized to support this intraseasonal variability was as follows: anomalies in tropical convection associated with the MJO drive variability in upper tropospheric circulation, and that variability can be seen in composite anomalies of height and wind by MJO phase (e.g., Madden and Julian, 1994; Zhang, 2005). Those circulation anomalies then drive variability in cloud cover and thus variability in UV radiation reaching the boundary layer, which in turn is seen in phase-to-phase variability in surface ozone concentrations in Mexico City. The cloud-UV radiation portion of our hypothesis is supported by Kerr and Fioletov (2008), who found that typical UV transmission ratios range between 0.3 and 0.8 for overcast conditions (Cede et al., 2002) and as little as 0.05 for thick cumulonimbus clouds (McArthur et al., 1999). It is also supported by An et al. (2008), who found a strong relationship between surface ozone concentrations in Beijing and surface UV radiation, particularly in summer, and noted that surface UV was up to $200 \%$ more sensitive to total cloud cover than was surface total radiation. The motivation to explore potential relationships between the MJO and surface ozone concentrations came from Barrett et al. (2012), who found differences as large as $25 \%$ of the daily mean in afternoon summer ozone concentrations in Santiago, Chile, by phase of the MJO and tied those differences to changes in cloud fraction associated with synoptic-scale circulation variability in different MJO phases. 
Table 1. Station names, locations, period of record, and number and type of observations.

\begin{tabular}{|c|c|c|c|c|c|c|c|c|}
\hline Station name & Abbreviation & $\begin{array}{r}\text { Latitude } \\
\left({ }^{\circ} \mathrm{N}\right)\end{array}$ & $\begin{array}{r}\text { Longitude } \\
\left({ }^{\circ} \mathrm{W}\right)\end{array}$ & $\begin{array}{r}\text { Elevation } \\
(\mathrm{m})\end{array}$ & $\begin{array}{r}\text { Period of } \\
\text { record }\end{array}$ & Variable & $\begin{array}{r}\text { Number of } \\
\text { observations }\end{array}$ & $\begin{array}{l}\text { Frequency of } \\
\text { observation }\end{array}$ \\
\hline Xalostoc & XAL & 19.3 & -99.2 & 2326 & 1986 to 2014 & Surface $\mathrm{O}_{3}$ & 221472 & Hourly \\
\hline Tlalnepantla & TLA & 19.4 & -99.1 & 2245 & 1986 to 2014 & Surface $\mathrm{O}_{3}$ & 230992 & Hourly \\
\hline Merced & MER & 19.5 & -99.1 & 2160 & 1986 to 2014 & Surface $\mathrm{O}_{3}$ & 219404 & Hourly \\
\hline Pedregal & PED & 19.5 & -99.2 & 2311 & 1986 to 2014 & Surface $\mathrm{O}_{3}$ & 217009 & Hourly \\
\hline UAM-Iztapalapa & UIZ & 19.4 & -99.1 & 2221 & 1986 to 2014 & Surface $\mathrm{O}_{3}$ & 194224 & Hourly \\
\hline Tacubaya & TCBY & 19.4 & -99.2 & 2313 & 1986 to 2014 & Surface wind & 7398 & $\begin{array}{l}\text { Daily (at } \\
\text { 12:00 LT) }\end{array}$ \\
\hline
\end{tabular}

\section{Data and methods}

The government monitoring network, Red Automática de Monitoreo Atmosférico (Automated Atmospheric Monitoring Network, RAMA) has been operational since January 1986 measuring all criteria pollutants, with instrumentation certified by the US Environmental Protection Agency (EPA). In particular, the instrument to measure ozone is produced by Thermo Environmental Instrument Model 49, by UV absorbance. The RAMA currently has 33 stations within the Mexico City basin, but only a few have records dating back to 1986.

We selected five stations with the longest periods of record (Table 1), one station from each of the five geographic regions in the metropolitan area identified by several previous studies and summarized by Raga et al. (2001). Hourly observations from Tlalnepantla (TLA, in the northwest sector of the city, NW), Xalostoc (XAL, in the northeast sector, NE), Merced (MER, in the Center), Pedregal (PED, in the southwest sector, SW), and Universidad Autónoma MetropolitanaIztapalapa (UIZ, in the southeast sector, SE) were available beginning in January 1986 and up to December 2014. See Fig. 1 for station locations and Table 1 for numbers of observations and elevations of each station. Since the ozone time series were non-stationary, standard anomalies (also called normalized anomalies) were calculated by subtracting a mean value from each observation and then dividing that result by a standard deviation (Wilks, 2011). Those mean values and standard deviations for each hour were estimated applying a 30-day (approximately monthly) running window, and the 30-day period was selected to avoid influence from both seasonal variability and also the long-term trend. We did not stratify by day of the week based on Stephens et al. (2008), who found that ozone in Mexico City exhibited relatively little variability by day of the week. Furthermore, we defined a "low" ozone concentration day as one with mean afternoon (12:00 to 16:00 local time) ozone standard anomalies (averaged across the five observing stations) below the 10th percentile. Percentiles were determined separately for each season using standard anomalies on all days in that season from 1986 to 2014. Similarly, we defined a "high" ozone concentration day as one where mean afternoon ozone

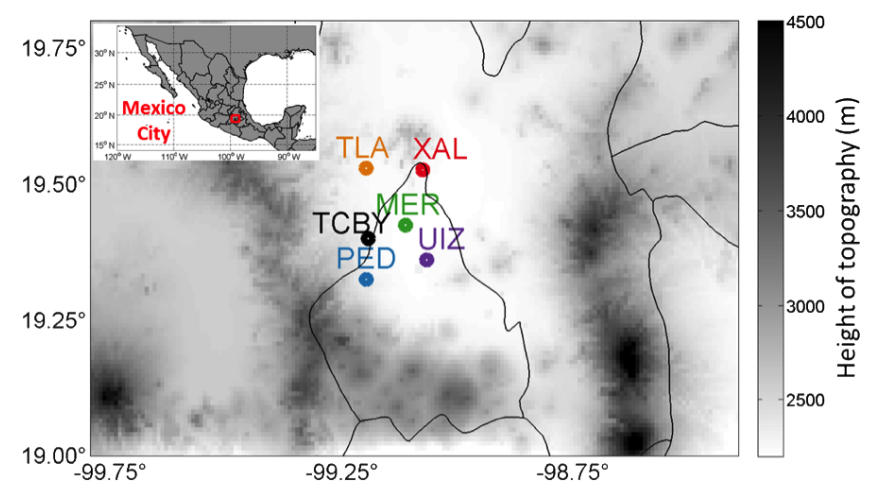

Figure 1. Locations of RAMA surface ozone stations used in this study (colored dots; abbreviations defined in Table 1) and topographic height (shaded, in $\mathrm{m}$ ) of the Mexico City metropolitan region. State boundaries shown as black contours. Surface meteorology station at Tacubaya (TCBY) also indicated. The inset in the upper right corner shows the location of Mexico City within Mexico.

standard anomalies exceeded the 90th percentile, again calculating winter and summer percentiles separately.

The MJO phase was determined using the Real-time Multivariate MJO (RMM) index (Wheeler and Hendon, 2004). The daily RMM is based on time series of two principal components derived from empirical orthogonal functions of equatorially $\left(5^{\circ} \mathrm{S}\right.$ to $\left.5^{\circ} \mathrm{N}\right)$ averaged $200 \mathrm{hPa}$ zonal wind, $850 \mathrm{hPa}$ zonal wind, and outgoing longwave radiation. The projection of daily data onto the empirical orthogonal functions serves as a time filter and makes the RMM useful in a real-time setting (Wheeler and Hendon, 2004). The RMM is divided into eight phases, and each phase corresponds to the broad geographic location of the MJO tropical convective signal on that day. An active MJO was defined in this study as one with RMM amplitude, which is the square root of the sum of the squares of the two principal components RMM1 and RMM2 (Wheeler and Hendon, 2004), greater than 1.0 (LaFleur et al., 2015). Each day's hourly standard ozone anomalies were binned using the phase of active MJO of that day. Mean values for each MJO phase were then cal- 
culated, first annually and then for each season (DJF and JJA).

Values of geopotential height (in $\mathrm{m}$ ) and $u$ and $v$ vector wind components at $250 \mathrm{hPa}$ (in m s $\mathrm{m}^{-1}$ ), along with total cloud cover, high cloud cover, and low cloud cover (expressed as fractions from 0 to 1 ) and downward UV radiation received at the surface (UV-B, in $\mathrm{W} \mathrm{m}^{-2}$ ) at 18:00 UTC (12:00 LT) were derived from the ERA-Interim reanalysis (Dee et al., 2011). We chose to examine $250 \mathrm{hPa}$ in part based on the results of Li et al. (2012), who connected intraseasonal ozone variability across east Asia with variability in uppertroposphere geopotential heights by MJO phase. Additionally, we are aware that cloud cover in reanalysis has biases, and we selected the ERA-Interim product because it specifically includes an improved deep convective cloud triggering mechanism over tropical land masses (Bechtold et al., 2004) and thus shows skill over other products (Dee et al., 2011).

We selected the winter (December-February; DJF) and summer (June-August; JJA) seasons for this study because of the homogeneity in synoptic-scale weather patterns in those seasons. More details on the climatological variability of ozone in Mexico City can be found in Klaus et al. (2001).

Finally, daily values of surface wind at the Tacubaya station (TCBY in Fig. 1) were taken from the NOAA National Centers for Environmental Information (NCEI) Integrated Surface Database (ISD; Smith et al., 2011). Anomalies of those values, calculated with respect to seasonal means, were binned by MJO phase to give composite anomalies for each season. For UV and total cloud cover in Mexico City itself, the gridded ERA-Interim value at the point closest to the mean latitude and longitude of the five RAMA stations was selected.

\section{Results}

\subsection{Variability of the ozone time series}

The diurnal cycle of ozone concentrations at each of the stations exhibited a daily minimum around 07:00 LT just prior to sunrise and a peak between 12:00 and 15:00 LT, with highest concentrations at the southernmost stations (PED and UIZ) and lowest in the northernmost station (XAL) (Fig. 2a). Additionally, highest ozone concentrations occurred 1-2 $\mathrm{h}$ earlier in spring (March-May; MAM) than in winter (December-February; DJF) at both PED and XAL (Fig. 2b), and peak ozone at PED in the south occurred one to two hours after peak ozone in XAL in the north, as a result of weak northeasterly surface winds transporting ozone and photochemical precursors southward during the day (Bossert, 1997).

Mean ozone concentrations in spring were nearly $30 \%$ higher at all stations than the rest of the year (Fig. 3, with observations smoothed by a 30-day running mean), and the effects of increased UV radiation during the "mid-summer
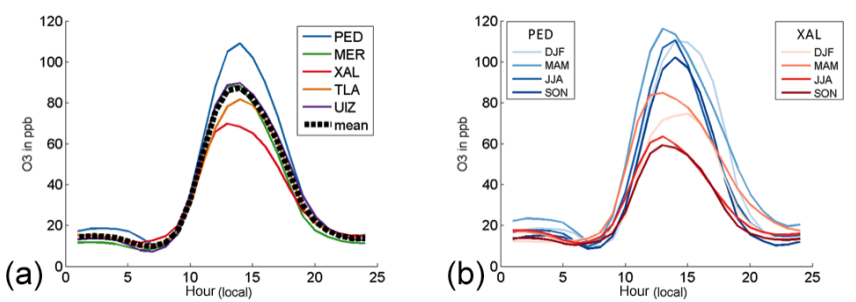

Figure 2. (a) Diurnal cycle of surface ozone concentrations (ppb) at five observing stations (colored lines), as well as the mean (black dotted line) for all seasons, 1986-2014. (b) Diurnal cycle of surface ozone concentrations for Pedregal (PED; blue lines) and Xalostoc (XAL; red lines) by season from the RAMA network, 1986-2014.

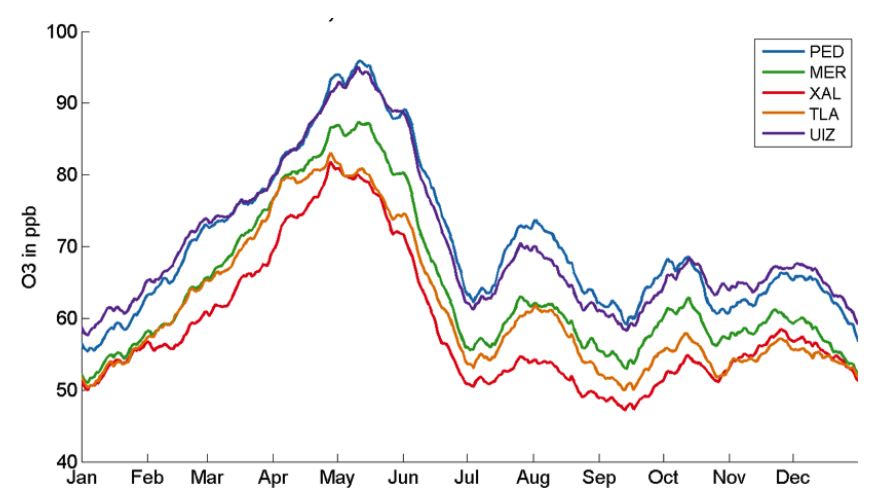

Figure 3. Annual cycles of surface ozone concentrations (ppb) for five observing stations for hours 12:00-16:00 LT (local time) from the RAMA network, 1986-2014. Observations are smoothed using a 30-day running mean.

drought" (canícula) (Magaña et al., 1999) were reflected as a secondary peak in ozone concentrations in August. Minimum $\mathrm{O}_{3}$ concentrations were observed in all five stations during September, when daily maximum precipitation was observed in Mexico City.

One of the challenges in examining intraseasonal variability of ozone is the need for a stationary record over a long period. In Mexico City, ozone concentrations have steadily decreased from the early 1990s to the 2010s (Fig. 4a; also Rodríguez et al., 2016) as a result of pollution-control measures (Molina and Molina, 2004). In order to remove the long-term trend, while keeping the intraseasonal variability at hourly resolution, hourly observations were converted to standard anomalies as described in Sect. 2. Results of this transformation of hourly observations to standard anomalies for station PED are shown in Fig. 4a (original hourly observations) and Fig. 4c (hourly standard anomalies). Standard anomalies for the other four stations show very similar results.

We note that overnight minimum observations from 1991 to 1993 were probably overestimated in the observational record (Fig. 4a), an artifact also seen in the other four stations (not shown). However, because in this study we focused 

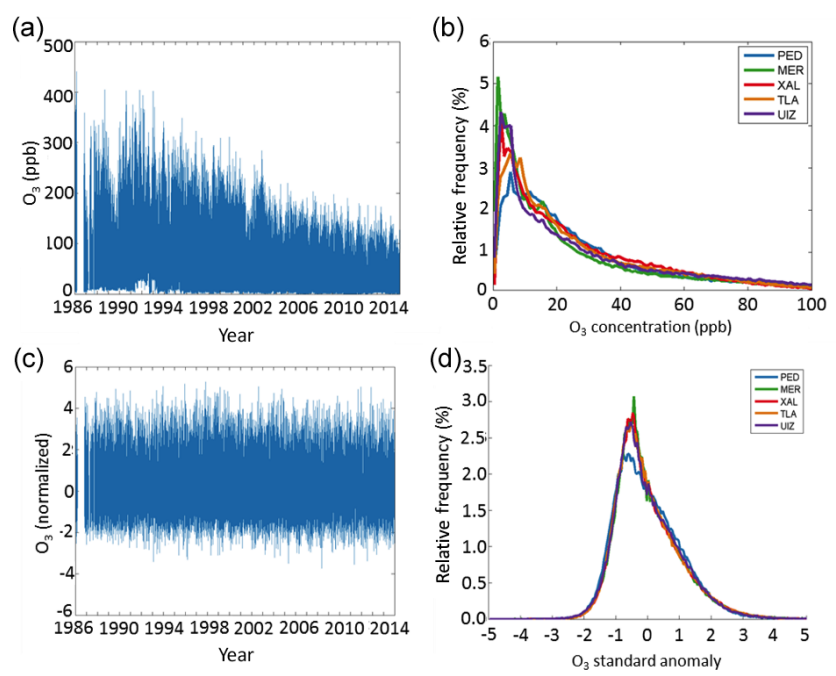

Figure 4. (a) Hourly observations of surface ozone concentrations (ppb) at Pedregal station (PED in Fig. 1). (b) Relative frequencies (in \%) of hourly ozone concentrations (ppb) at five observing stations, 1986-2014. (c) Standard anomalies of hourly surface ozone concentrations at PED. (d) Relative frequencies (in \%) of standard anomalies of hourly ozone concentrations at five observing stations from the RAMA network, 1986-2014.

on afternoon values (from 12:00 to 16:00 LT), that potential overestimation did not materially impact our results.

By transforming each hourly observation into a standard anomaly, the distribution of relative frequencies shifted from highly non-Gaussian, with peaks near zero and very long right tails (Fig. 4b), to more Gaussian, with peaks near -0.5 and reduced skewness (Fig. 4d). Although the peaks in these transformed distributions were less than zero, and the right tails were longer than the left tails, the means of each of the distributions of standard anomalies in Fig. 4d were very near zero, falling between -0.03 and 0 .

\subsection{Synoptic patterns associated with low and high ozone}

Before examining ozone variability by MJO phase, it was important to first establish the synoptic-scale patterns associated with days of low and high ozone concentrations (defined in Sect. 2) in each season.

In winter (DJF), the synoptic pattern on days with low afternoon surface ozone concentration featured a $250 \mathrm{hPa}$ ridge over northwest Mexico and the southwest US (height anomalies up to $+50 \mathrm{~m}$ ) and a $250 \mathrm{hPa}$ trough over central, eastern, and southern Mexico and the southern and eastern US (height anomalies -10 to $-40 \mathrm{~m}$ ) (Fig. $5 \mathrm{a}$ ). Mean circulation at $250 \mathrm{hPa}$ on low DJF ozone days was nearly westerly off the central Mexican west coast turning to southwesterly over central Mexico (Fig. 5a). This synoptic pattern would favor enhanced cloudiness over Mexico City (and thus reduced UV radiation and lower ozone concentrations) via two mechanisms: first, through quasi-geostrophic ascent associated with the $250 \mathrm{hPa}$ trough, and second, through advection of moisture and high-level clouds from the subtropical Pacific (around $20^{\circ} \mathrm{N}$ ) associated with westerly and westnorthwesterly winds (Fig. 5a). Indeed, positive total cloud fraction anomalies were seen with this height and circulation pattern, and those cloud fraction anomalies $(+0.05$ to +0.10$)$ extended over central and southern Mexico and northeastward into the Gulf of Mexico (Fig. 5b). Those anomalies were likely comprised primarily of high cloud $(+0.05$ to +0.15 ; Fig. $5 c)$, given the resemblance between the pattern of total cloud cover (Fig. 5b) and high cloud cover (Fig. 5c). A region of positive low cloud-cover anomalies (up to +0.15 ; Fig. 5d) was also seen in central Mexico on winter days with lowest $\mathrm{O}_{3}$ concentrations, likely associated with surface wind convergence over the Sierra Madre Oriental, although low cloud fraction anomalies over Mexico City itself were less than +0.05 .

The synoptic pattern for winter days with high surface ozone concentration was opposite that for the low ozone days. Over northwest Mexico and the southwest US, a trough was seen at $250 \mathrm{hPa}$ (anomalies -10 to $-70 \mathrm{~m}$ ), while a ridge was seen over central, southern, and eastern Mexico and the southern and eastern US (anomalies to $+50 \mathrm{~m}$; Fig. 5e). Circulation at $250 \mathrm{hPa}$ over central Mexico was southwesterly (compared to westerly for low ozone days). Negative total cloud fraction anomalies $(-0.05$ to -0.15$)$ over central and southern Mexico were associated with this circulation pattern (Fig. 5f). This pattern would promote clearer than normal skies (and thus enhanced UV radiation and surface ozone production) both by favoring quasi-geostrophic subsidence over central Mexico (associated with the above-normal heights and ridging at $250 \mathrm{hPa}$ ) and by advecting dry, cloudfree air toward central Mexico from the tropical East Pacific Ocean originating near $10^{\circ} \mathrm{N}$ (Fig. 5g). Similar to low ozone days, most of the negative total cloud fraction anomalies were likely the result of the reduction in the presence of high cloud (Fig. $5 \mathrm{~g}$ ), given similarity of the anomaly patterns between total (Fig. 5f) and high (Fig. 5g) cloud fraction. The low cloud fraction anomaly over Mexico City itself (Fig. 5h) was close to zero, although negative low cloud fraction anomalies $(-0.05$ to -0.15$)$ were seen over the low-land states bordering the Gulf of Mexico (Fig. 5h).

Summer days with low surface ozone concentration featured a slight anomalous ridge (height anomalies of +5 to $+15 \mathrm{~m}$ ) over northern Mexico and much of the US (Fig. 6a). This synoptic-scale pattern would favor cloudiness because positive geopotential height anomalies at $250 \mathrm{hPa}$ over northern Mexico and the southwest US would be associated with a stronger summer anticyclone, signifying a more intense monsoon circulation, easterly winds at $250 \mathrm{hPa}$ in central and southern Mexico (Fig. 6a), and precipitation in central and southern Mexico. Indeed, low ozone days featured positive anomalies in total cloud fraction (Fig. 6b), high cloud fraction (Fig. 6c), and low cloud fraction (Fig. 6d), with 

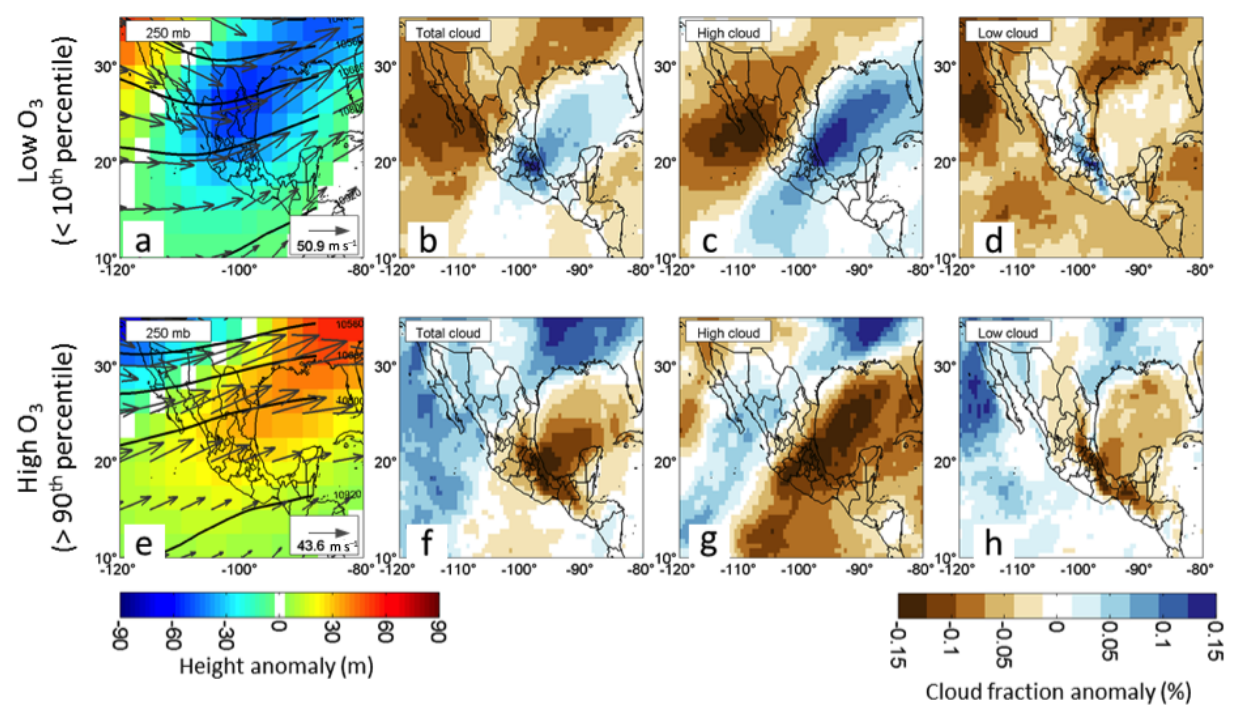

Figure 5. (a) Height (contoured, in $\mathrm{m}$ ), height anomalies (shaded, in $\mathrm{m}$ ), and mean winds (vectors) at $250 \mathrm{hPa}$ for winter (DJF) days with standard anomalies of afternoon (12:00 to 16:00 LT) surface ozone at the five observing stations (Fig. 1) below the 10th percentile. (bd) Anomalies (in \%) of total cloud fraction, high cloud fraction, and low cloud fraction, respectively, for the same winter days with standard anomalies of afternoon surface ozone concentrations below the 10th percentile. (e-h) Same as in panels (a-d), but for winter days with mean afternoon surface ozone concentrations above the 90th percentile. Percentile calculations based on hourly observations from 1986-2014. Height, wind, and cloud fraction data from ERA-Interim; ozone concentrations from RAMA stations.
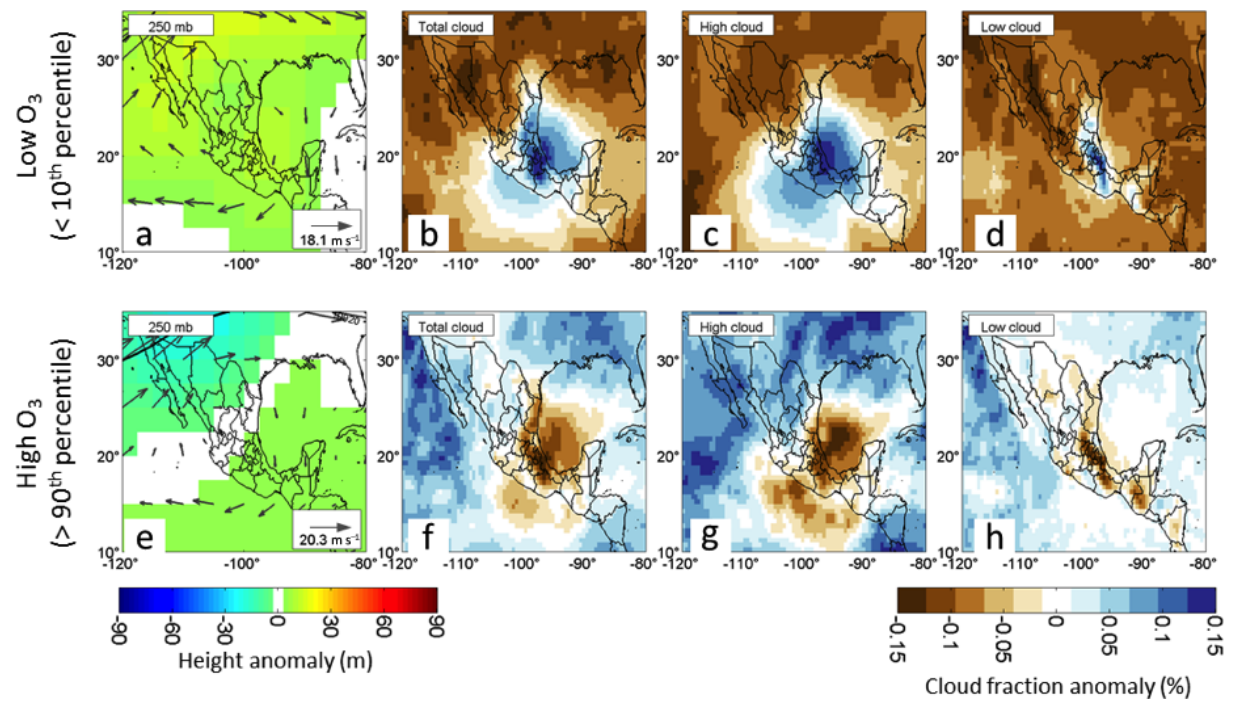

Figure 6. As in Fig. 5, but for summer (JJA) days.

anomalies of each fractional cloud-cover variable ranging from +0.05 to +0.15 . The regions of positive total and high cloud-cover anomalies extended over much of central Mexico, but anomalies in low cloud fraction were confined to Mexico City and the states bordering it (Fig. 6d). Summer days with high ozone concentration featured less ridging over northwestern Mexico and the southwest US, with $250 \mathrm{hPa}$ height anomalies of -10 to $-20 \mathrm{~m}$ (Fig. 6e). This synopticscale pattern with weaker ridging over northwest Mexico and the southwest US, and stronger ridging over Central Amer- ica, is opposite of the climatological monsoon circulation and would favor less precipitation in central Mexico. Indeed, negative anomalies in fraction of total cloud cover (Fig. 6f), high cloud cover (Fig. 6g), and low cloud cover (Fig. 6h) were seen on days with high ozone concentrations, with anomaly magnitudes of -0.05 to -0.15 over much of central and southern Mexico (total and high cloud cover) and the states bordering Mexico City and along the Sierra Madre Occidental (Fig. 6h). In the next section, these seasonal ozone pat- 
tern composites are compared to pattern composites for MJO phases with greatest ozone anomalies.

\subsection{Intraseasonal ozone variability}

On an annual basis, afternoon (12:00 to 16:00 LT) surface ozone concentrations in Mexico City were found to vary by MJO phase. Highest ozone concentrations were noted on days when MJO was active and in phases 3, 4, and 5, while lowest ozone concentrations were noted on days when the MJO was active and in phases 1 and 2 (Fig. 7a). This variability was seen at all five stations, regardless of geographic position within the basin. Normalized anomalies of surface UV radiation and total cloud fraction from ERA-Interim reanalysis strongly supported the observed surface ozone variability: MJO phases with highest ozone concentrations also had highest UV anomalies and lowest total cloud fraction anomalies, while MJO phases with lowest ozone concentrations had the most negative UV and the most positive cloud fraction anomalies (Fig. 7d). We found this agreement remarkable, particularly because the two data sets independently presented the same intraseasonal pattern.

On a seasonal basis, surface ozone concentrations in Mexico City were also found to vary by MJO phase. However, the dependence on phase was found to change between winter and summer, meaning a phase associated with higher ozone concentrations in winter would not necessarily be associated with higher ozone concentrations in summer. We attribute these differences to seasonality in both the convective properties of the MJO itself (e.g., Zhang and Dong, 2004; Wu et al., 2006) and in the extratropical atmosphere, whose circulation the MJO modulates (Gloeckler and Roundy, 2013). Despite the phase-to-phase variability in maximum and minimum ozone concentrations throughout the year, in all seasons, there remained good agreement between phases with highest (lowest) ozone concentrations and phases with highest (lowest) UV and lowest (highest) total cloud fraction. That is, the sunnier phases were consistently associated with the highest ozone concentrations.

In winter months (DJF), highest ozone concentrations were found on days when the MJO was in phase 2, and lowest ozone concentrations were found on days when the MJO was in phase 8 (Fig. 7b). Highest UV radiation, and lowest total cloud fraction, were seen on days when the MJO was in phase 2, and lowest UV radiation and second-highest cloud fraction were seen on days when the MJO was in phase 8 (Fig. 7e). In summer months (JJA), highest ozone concentrations were found on days when the MJO was in phases 5, 6, and 7, and lowest ozone concentrations were found on days when the MJO was in phases 1 and 8 (Fig. 7c). Highest UV radiation, and lowest total cloud fraction, was seen on days when the MJO was in phase 6, and lowest UV radiation and highest total cloud fraction were seen on days when the MJO was in phase 1 . In both winter and summer, UV radiation and cloud-cover anomalies strongly supported observed surface
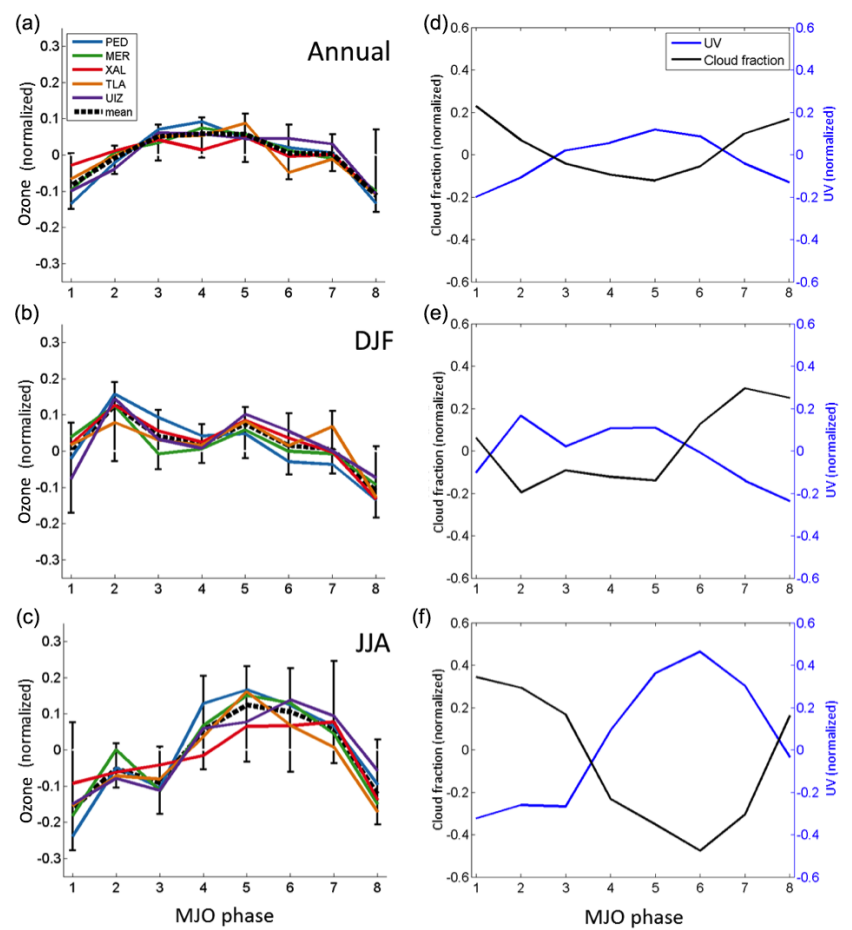

Figure 7. Mean standard anomalies of midday (hours 12:0016:00 LT) surface ozone concentrations by active MJO phase for (a) annual, (b) DJF, and (c) JJA. Stations indicated by line color. Error bars indicate largest and smallest standard anomaly values for all stations; dashed black curve indicates mean value. All surface ozone observations from the RAMA network, 1986-2014. (d) Standard anomalies of UV radiation (blue curves) and total cloud fraction (black curves) for each active MJO phase for the entire year. (e, f) Same as panel (d) but for DJF and JJA, respectively. UV and cloud fraction data from ERA-Interim reanalysis, 1986-2014, for the grid closest to Mexico City.

ozone anomalies, whereby the cloudiest MJO phases featured lowest ozone and the sunniest phases featured highest ozone. We again consider this agreement remarkable, given the independence of the ozone and reanalysis data sets. Summer months (JJA) featured the greatest range in mean ozone concentrations by MJO phase: a difference in 0.25 standard anomaly units between the phases with the highest ozone concentrations (phases 5 and 6) and the phases with the lowest ozone concentrations (phases 1 and 8) (Fig. 7c). Summer months also featured the largest spread in both UV and total cloud fraction standard anomalies (Fig. 7f).

An examination of the frequency of "extreme" ozone days in each MJO phase (here a day with an "extreme" ozone value was defined for each season as an afternoon standard anomaly either above the 90th percentile value or below the 10th percentile value) provides additional insight into the character of the MJO modulation of ozone. In both winter and summer, the phases associated with highest ozone concentrations (phase 2 in winter and phase 6 in summer) 
Table 2. Relative frequency of extreme ozone days in winter (top two rows) and summer (bottom two rows). A high ozone day was defined as one with a mean afternoon (12:00 to 16:00 LT) ozone anomaly across the five observing stations greater than the long-term (1986-2014) 90th percentile. Similarly, a low ozone day was defined as one with a mean afternoon anomaly across the 5 observing stations less than the long-term 10th percentile. Values in bold (winter phase 2; summer phase 6) indicate phases with highest mean ozone concentrations in those seasons; values in italics (winter phase 8; summer phase 1) indicate phases with lowest mean ozone concentrations in those seasons. The number of days $(n)$ in each active phase is given for each season, and is used to estimate the relative frequency.

\begin{tabular}{|c|c|c|c|c|c|c|c|c|}
\hline Winter (DJF) & $\begin{array}{l}\text { Phase } 1 \\
n=134\end{array}$ & $\begin{array}{l}\text { Phase } 2 \\
n=169\end{array}$ & $\begin{array}{l}\text { Phase } 3 \\
n=249\end{array}$ & $\begin{array}{l}\text { Phase } 4 \\
n=222\end{array}$ & $\begin{array}{l}\text { Phase } 5 \\
n=226\end{array}$ & $\begin{array}{l}\text { Phase } 6 \\
n=254\end{array}$ & $\begin{array}{l}\text { Phase } 7 \\
n=282\end{array}$ & $\begin{array}{l}\text { Phase } 8 \\
n=187\end{array}$ \\
\hline $\begin{array}{l}\text { Relative frequency of days with } \mathrm{O}_{3} \text { concentration } \\
\text { greater than the } 90 \text { th percentile }\end{array}$ & $9.7 \%$ & $10.1 \%$ & $7.6 \%$ & $8.1 \%$ & $12.8 \%$ & $9.8 \%$ & $12.4 \%$ & $8.6 \%$ \\
\hline $\begin{array}{l}\text { Relative frequency of days with } \mathrm{O}_{3} \text { concentration } \\
\text { less than the } 10 \text { th percentile }\end{array}$ & $9.0 \%$ & $7.1 \%$ & $7.2 \%$ & $8.1 \%$ & $7.5 \%$ & $9.8 \%$ & $12.4 \%$ & $13.9 \%$ \\
\hline Summer (JJA) & $\begin{array}{l}\text { Phase } 1 \\
n=351\end{array}$ & $\begin{array}{l}\text { Phase } 2 \\
n=267\end{array}$ & $\begin{array}{l}\text { Phase } 3 \\
n=112\end{array}$ & $\begin{array}{l}\text { Phase } 4 \\
n=114\end{array}$ & $\begin{array}{l}\text { Phase } 5 \\
n=165\end{array}$ & $\begin{array}{l}\text { Phase } 6 \\
n=137\end{array}$ & $\begin{array}{l}\text { Phase } 7 \\
n=121\end{array}$ & $\begin{array}{l}\text { Phase } 8 \\
n=161\end{array}$ \\
\hline $\begin{array}{l}\text { Relative frequency of days with } \mathrm{O}_{3} \text { concentration } \\
\text { greater than the } 90 \text { th percentile }\end{array}$ & $8.6 \%$ & $6.7 \%$ & $3.6 \%$ & $10.5 \%$ & $9.7 \%$ & $11.7 \%$ & $11.6 \%$ & $8.7 \%$ \\
\hline $\begin{array}{l}\text { Relative frequency of days with } \mathrm{O}_{3} \text { concentration } \\
\text { less than the } 10 \text { th percentile }\end{array}$ & $17.1 \%$ & $9.0 \%$ & $10.7 \%$ & $4.4 \%$ & $5.5 \%$ & $3.7 \%$ & $9.1 \%$ & $14.9 \%$ \\
\hline
\end{tabular}

featured the fewest occurrences of days with extremely low ozone (days with concentrations below the 10th percentile; Table 2). Those phases also featured either the highest (in summer) or near-highest (in winter) occurrences of days with concentrations above the 90th percentile (Table 2). Furthermore, the phases associated with lowest ozone concentration (phase 8 in winter and phase 1 in summer) featured the highest occurrences of days with low ozone (Table 2) and belownormal occurrence of days with high ozone. These results confirm that one manner in which the MJO modulates ozone concentration in Mexico City is to reduce (or augment) the frequency of days with afternoon ozone concentrations either below the 10th or above the 90th percentiles.

To examine physical mechanisms for the observed variability in ozone concentration and cloud cover by MJO phase, composite anomalies of $250 \mathrm{hPa}$ height and $u$ and $v$ wind components were created for each active MJO phase for each season. Seasonal anomalies of total cloud fraction, high cloud fraction, and low cloud fraction were also composited for each active MJO phase. In both seasons, anomalies of each variable were found for all eight MJO phases. However, for the remainder of this paper, we focus only on the synoptic-scale conditions in phases with maximum and minimum surface ozone. In DJF, minimum ozone concentrations occurred on days when the MJO was active and in phase 8 . In that phase, anomalous $250 \mathrm{hPa}$ ridging was seen over northwest Mexico and the southwest US (anomalies up to $+50 \mathrm{~m}$ ) and anomalous $250 \mathrm{hPa}$ troughing over northeast Mexico and the southeastern US (anomalies to $-60 \mathrm{~m}$ ) (Fig. 8a). This height pattern resembled the seasonal pattern for winter days with above-normal cloudiness and low ozone (Fig. 5a), with troughing over central Mexico favoring both cloud formation via ascent and cloud advection from the subtropical East Pacific Ocean. Indeed, on days in MJO phase 8, total cloud-cover anomalies were positive over nearly all of Mexico, ranging from +0.05 to +0.15 (Fig. 8b). Anomalies in high cloud cover were smaller in magnitude (up to +0.05 ), and over Mexico City, high cloud-cover anomalies were zero (Fig. 8c). Positive low cloud anomalies were confined to the states to the east of Mexico City (Fig. 8d), which when combined with high cloud-cover anomalies, suggest that the anomalies in total cloud cover (Fig. 8b) were composed of anomalies at multiple levels.

Maximum winter ozone concentrations occurred on days when the MJO was active and in phase 2, and on those days, a synoptic-scale pattern opposite to that of phase 8 was seen: anomalous $250 \mathrm{hPa}$ troughing was seen over northern Mexico and the south-central US (height anomalies of -10 to $-30 \mathrm{~m}$ ) and anomalous $250 \mathrm{hPa}$ ridging was seen over central and southern Mexico and Central America (height anomalies +5 to $+20 \mathrm{~m}$ ) (Fig. 8e). This height pattern resembled the seasonal pattern for high ozone and low cloud fraction (Fig. 5e), with anomalous ridging favoring clearer than normal skies via subsidence and advection of dry air from the tropical East Pacific. Indeed, below-normal total cloud fraction (anomalies -0.05 to -0.15 ; Fig. $8 \mathrm{f}$ ), high cloud fraction (anomalies -0.05 to -0.15 ; Fig. $8 \mathrm{~g}$ ), and low cloud fraction (anomalies -0.05 to -0.10 ; Fig. $8 \mathrm{~h}$ ) were seen on days when the MJO was in phase 2 over much of central and southern Mexico.

In JJA, minimum ozone concentrations occurred on days when the MJO was in phase 1 . In that phase, anomalous $250 \mathrm{hPa}$ ridging was seen over northwest Mexico and the southwest US (anomalies up to $+20 \mathrm{~m}$ ) and anomalous $250 \mathrm{hPa}$ troughing in the tropical East Pacific Ocean (anomalies to $-20 \mathrm{~m}$ ) (Fig. 9a). This height pattern resembled the seasonal pattern for summer days associated with belownormal cloudiness and high ozone (Fig. 6a), with ridging to 

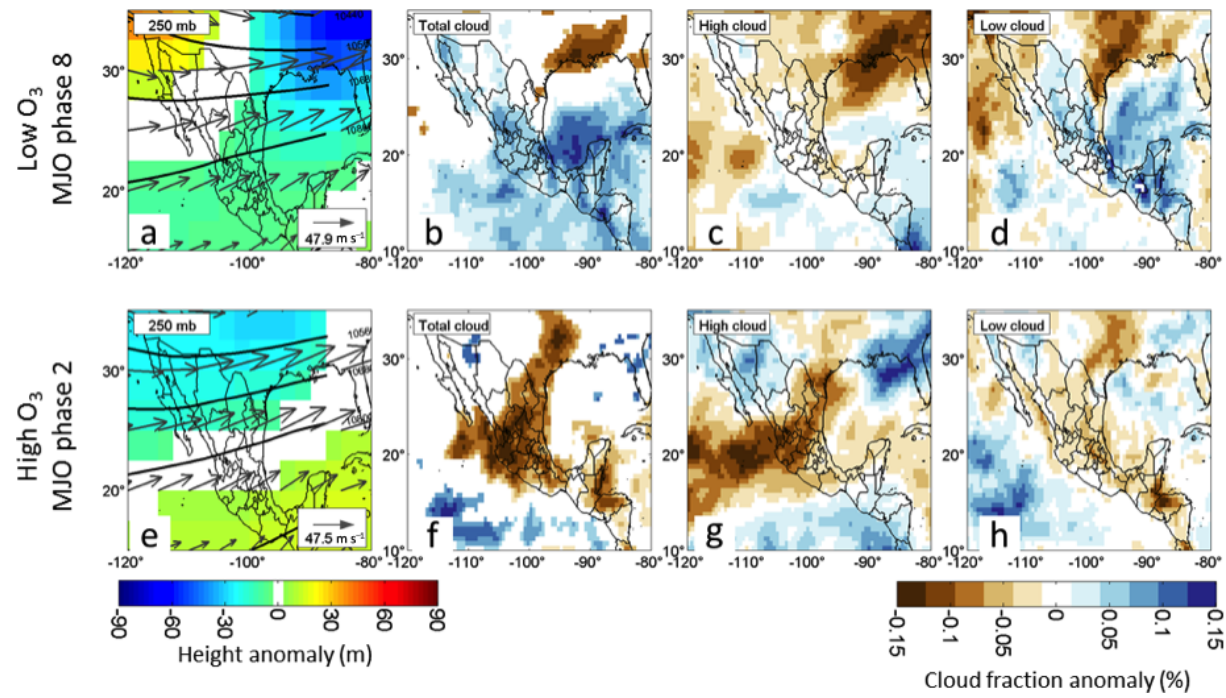

Figure 8. Composites of $250 \mathrm{hPa}$ height (in $\mathrm{m}$ ), height anomaly (in $\mathrm{m}$ ), and mean wind (a), and total cloud fraction (in \%; b), high cloud fraction (in \%; c), and low cloud fraction (in \%; d) for winter days in active MJO phase 8. (e-h) Same as panels (a-d) but for winter days in active MJO phase 2 . Phases 8 and 2 were the phases with lowest and highest respective winter ozone concentrations in Mexico City.
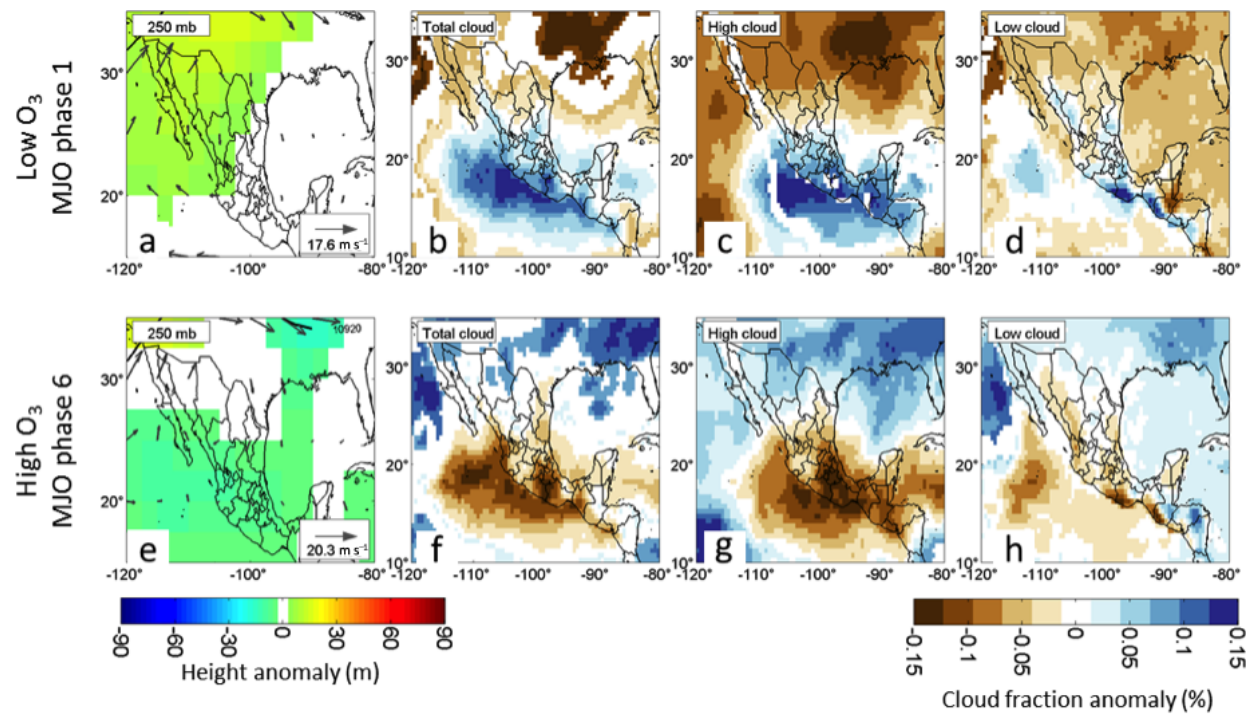

Figure 9. As in Fig. 8, but for summer days in active MJO phase 1 (a-d) and active MJO phase 6 (e-h). Phases 1 and 6 were the phases with lowest and highest respective summer ozone concentrations in Mexico City.

the north characteristic of the summer monsoon in central Mexico. Indeed, above-normal total cloud fraction ( +0.05 to +0.15 ; Fig. 9b), above-normal high cloud fraction $(+0.05$ to +0.15 ; Fig. $9 \mathrm{c}$ ), and above-normal low cloud fraction $(+0.05$ to +0.10 ; Fig. $9 \mathrm{~d})$ were seen over central and southern Mexico for days in MJO phase 1. Summer maximum ozone concentrations were seen on days when the MJO was in phase 6 . In that phase, a weaker-than-normal ridge at $250 \mathrm{hPa}$ was seen as anomalous heights of -10 to $-20 \mathrm{~m}$ over much of central Mexico (Fig. 9e). This height pattern resembled the seasonal pattern for summer days associated with above-normal cloudiness and high ozone (Fig. 6e), as it is largely opposite to that which characterizes the central Mexico summer monsoon. Indeed, below-normal total cloud fraction ( -0.05 to -0.15 ; Fig. 9f), high cloud fraction $(-0.05$ to -0.15 ; Fig. $9 \mathrm{~g})$, and low cloud fraction $(-0.05$; Fig. 9h) were all seen on days when the MJO was in phase 6.

The final physical variable examined for intraseasonal variability by MJO phase was the surface wind vector at 18:00 UTC (12:00 LT) at Tacubaya (TCBY in Fig. 1) in the center-west portion of the metropolitan area (Fig. 1). In winter, days in phase 8 (lowest ozone concentrations) 
featured anomalous northeasterly surface winds (blue vectors; Fig. 10), resulting in observed wind speeds up to $40 \%$ stronger than climatology (red vectors in Fig. 10). Days in phase 2 (highest ozone concentrations) featured anomalous westerly winds, resulting in winds up to $50 \%$ weaker in magnitude (Fig. 10) than climatology. In summer, days in phases 8 and 1 (lowest ozone concentrations) featured surface winds very similar to climatology in both magnitude and direction. In summer, the wind direction on days in phase 8 was more from the north-northwest, while climatology was from the north-northeast, resulting in a very small westerly anomaly. Days in phase 6 (highest ozone concentrations) also featured winds with similar direction as the seasonal mean, but with speeds up to $30 \%$ faster (Fig. 10). Despite these variations by MJO phase across all seasons, we do not consider the surface wind anomalies to be physically consistent or representative of a large-scale pattern, for two reasons. First, because Mexico City is located in a basin, surface flow fields do not normally respond to synoptic-scale pattern variability (Stephens et al., 2008). Indeed, the majority of the day-to-day variability in surface wind speed and direction is controlled by mesoscale, thermally driven mountainvalley circulations (Doran et al., 1998). With the exception of "cold surge" events in winter that have been associated with cloudy days, the two dominant ozone patterns identified by de Foy et al. (2005) only served to identify whether the ozone maximum would be in the southern or northern parts of the metropolitan area. Second, the wind anomalies by MJO phase resulted in only subtle changes in either direction, or speed, or both (Fig. 10). Moreover, none of the wind anomalies identified in DJF would meet the northerly "cold surge" of de Foy et al. (2005), suggesting that the "cold surge" events can occur during different MJO phases unrelated to modulation from the MJO. Finally, the smallness of the surface wind variability by MJO phase supports our argument that variability in surface ozone concentrations by MJO phase are primarily driven by variability in total cloud cover and surface UV radiation, which in turn are related to anomalies in upper-tropospheric circulation.

\section{Conclusions}

In this study, we investigated the intraseasonal variability of winter (DJF) and summer (JJA) surface ozone concentrations in Mexico City. After standardizing over 1000000 hourly observations of surface ozone from five stations around the metropolitan area, we binned them by phase of the active MJO. We found that highest winter ozone concentrations occurred on days when the MJO was active and in phase 2 (in the Indian Ocean), and highest summer ozone concentrations occurred on days when the MJO was active and in phase 6 (in the western Pacific Ocean) in summer. Lowest ozone concentrations were found on winter days in MJO phase 8 (in the eastern Pacific Ocean) and summer phase 1 (in the Atlantic

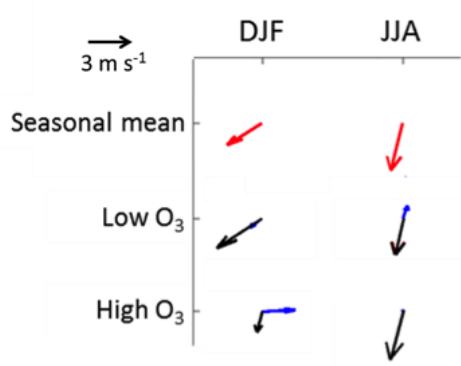

Figure 10. Mean $10 \mathrm{~m}$ winds at Tacubaya station (TCBY in Fig. 1) at 18:00 UTC (12:00 LT). Mean surface wind vectors for each season, DJF and JJA, are on row one and indicated by red arrows. Mean (black arrows) and anomaly (blue arrows) vectors for the MJO phases associated with lowest surface ozone (phase 8 in DJF and phase 1 in JJA) are on the middle row. Mean (black arrows) and anomaly (blue arrows) vectors for the MJO phases associated with highest surface ozone (phase 2 in DJF and phase 6 in JJA) are on the bottom row. Note that the mean winds for low ozone in DJF and high ozone in JJA are very similar to the seasonal mean winds, so the anomaly (blue) vector is very small. All wind data are from NOAA National Centers from Environmental Information, 19862014.

Ocean). This intraseasonal variability in surface ozone concentrations agreed well with anomalies in cloud cover and UV-B radiation: phases with highest ozone concentration had highest UV-B radiation and lowest cloud cover, while phases with lowest ozone concentration had lowest UV-B radiation and highest cloud cover. This agreement was found for both winter and summer. Circulation anomalies at $250 \mathrm{hPa}$ were found to support the observed variability in ozone and cloud cover. In winter, height and circulation anomalies favoring reduced cloudiness, and thus elevated surface ozone, were found on days when the MJO was in phase 2, and height and circulation anomalies favoring enhanced cloudiness, and thus reduced surface ozone, were found on days when the MJO was in phase 8 . In summer, monsoon-like $250 \mathrm{hPa}$ circulation patterns that favor enhanced cloudiness, and thus reduced surface ozone, were found on days when the MJO was in phase 1 , and $250 \mathrm{hPa}$ circulation patterns opposite to the monsoon, favoring reduced cloudiness and thus elevated surface ozone, were found on days when the MJO was in phase 6 . We did not find physically meaningful variability in surface wind direction by MJO phase, despite earlier studies suggesting a relationship between surface wind and surface ozone in Mexico City. This suggests that the intraseasonal variability in both summer and winter surface ozone by MJO phase is driven primarily by variability in cloud cover via modulation of upper-troposphere circulation. 


\section{Data availability}

Hourly ozone concentrations for Mexico City are available from the governmental monitoring network and can be downloaded from http://www.aire.cdmx.gob.mx/default. php?opc='aKBh'.

The ERA-Interim reanalysis is available to the community courtesy of ECMWF from http://apps.ecmwf.int/datasets/ data/interim-full-daily/levtype $=$ sfc/ (Dee et al., 2011).

Acknowledgements. Partial funding for Bradford S. Barrett was provided by the Fulbright Scholar program of the US State Department and the Programa de Estancias de Investigación, Dirección General de Personal Académico, Universidad Nacional Autónoma de México (DGAPA-UNAM). The air quality data were obtained from the databases of the Mexico City's Air Quality Monitoring Network, operated by the Ministry of Environment of Mexico City. ERA-Interim data were provided courtesy of ECMWF.

Edited by: N. Harris

Reviewed by: two anonymous referees

\section{References}

An, J. L., Wang, Y. S., Li, X., Sun, Y., and Shen, S H.: Relationship between surface UV radiation and air pollution in Beijing, Environ. Sci., 29, 1054-1058, 2008 (in Chinese).

Barrett, B. S., Fitzmaurice, S. J., and Pritchard S. R.: Intraseasonal variability of surface ozone in Santiago, Chile: modulation by phase of the Madden-Julian Oscillation (MJO), Atmos. Environ., 55, 55-62, 2012.

Bechtold, P., Chaboureau, J. P., Beljaars, A. C. M., Betts, A. K., Kohler, M., Miller, M., and Redelsperger, J.-L.: The simulation of the diurnal cycle of convective precipitation over land in a global model, Q. J. Roy. Meteor. Soc., 130, 3119-3137, 2004.

Bossert, J. E.: An investigation of flow regimes affecting the Mexico City Region, J. Appl. Meteorol., 36, 119-140, 1997.

Cede, A., Blumthaler, M., Luccini, E., Piacentini, R. D., and Numez, L.: Effects of clouds on erythemal and total irradiance as derived from data of the Argentine Network, Geophys. Res. Lett, 29, 2223-2227, doi:10.1029/2002GL015708, 2002.

Dee, D. P., Uppala, S. M., Simmons, A. J., Berrisford, P., Poli, P., Kobayashi, S., Andrae, U., Balmaseda, M. A., Balsamo, G., Bauer, P., Bechtold, P., Beljaars, A. C. M., van de Berg, L., Bidlot, J., Bormann, N., Delsol, C., Dragani, R., Fuentes, M., Geer, A. J., Haimberger, L., Healy, S. B., Hersbach, H., Hólm, E. V., Isaksen, L., Kållberg, P., Köhler, M., Matricardi, M., McNally, A. P., Monge-Sanz, B. M., Morcrette, J.-J., Park, B.-K., Peubey, C., de Rosnay, P., Tavolato, C., Thépaut, J.-N., and Vitart, F.: The ERA-Interim reanalysis: configuration and performance of the data assimilation system, Q. J. Roy. Meteor. Soc., 137, 553-597, 2011

de Foy, B., Caetano, E., Magaña, V., Zitácuaro, A., Cárdenas, B., Retama, A., Ramos, R., Molina, L. T., and Molina, M. J.: Mexico City basin wind circulation during the MCMA-2003 field campaign, Atmos. Chem. Phys., 5, 2267-2288, doi:10.5194/acp-52267-2005, 2005.
Doran, J. C., Abbot, S., Archuleta, J., and Bian, X.: The IMADAAVER boundary layer experiment in the Mexico City area, B. Am. Meteorol. Soc., 79, 2497-2508, 1998.

El-Nouby Adam, M. and Ahmed, E. A.: An assessment of the ratio of ultraviolet-B to broadband solar radiation under all cloud conditions at a subtropical location, Adv. Space Res., 57, 764-775, 2016.

Fast, J. D. and Zhong, S.: Meteorological factors associated with inhomogeneous ozone concentrations within the Mexico City basin, J. Geophys. Res., 103, 18927-18946, 1998.

Gloeckler, L. C. and Roundy, P. E.: Modulation of the extratropical circulation by combined activity of the Madden-Julian Oscillation and equatorial Rossby waves during boreal winter, Mon. Weather Rev., 141, 1347-1357, 2013.

Huerta, G., Sansó, B., and Stroud, J. R.: A spatiotemporal model for Mexico City ozone levels, Appl. Statist., 53, 231-248, 2004.

Kerr, J. B. and Fioletov, V. E.: Surface ultraviolet radiation, Atmos. Ocean, 46, 159-184, 2008.

Klaus, D., Poth, A., Voss, M., and Jáuregui, E.: Ozone distributions in Mexico City using principal component analysis and its relation to meteorological parameters, Atmósfera, 14, 171-188, 2001.

LaFleur, D. M., Barrett, B. S., and Henderson, G. R.: Some climatological aspects of the Madden-Julian Oscillation (MJO), J. Climate, 28, 6039-6053, 2015.

Lei, W., de Foy, B., Zavala, M., Volkamer, R., and Molina, L. T.: Characterizing ozone production in the Mexico City Metropoli$\tan$ Area: a case study using a chemical transport model, Atmos. Chem. Phys., 7, 1347-1366, doi:10.5194/acp-7-1347-2007, 2007.

Li, K.-F., Tian, B., Waliser, D. E., Schwartz, M. J., Neu, J. L., Worden, J. R., and Yung, Y. L.: Vertical structure of MJO-related subtropical ozone variations from MLS, TES, and SHADOZ data, Atmos. Chem. Phys., 12, 425-436, doi:10.5194/acp-12425-2012, 2012.

Madden, R. and Julian, P.: Detection of a 40-50 day oscillation in the zonal wind in the tropical Pacific, J. Atmos. Sci., 28, 702708, 1971.

Madden, R. and Julian, P.: Description of global-scale circulation cells in the tropics with a 40-50 day period, J. Atmos. Sci., 29, 1109-1123, 1972.

Madden, R. and Julian, P.: Observations of the 40-50 day tropical oscillation: a review, Mon. Wea. Rev., 122, 814-837, 1994.

Magaña, V., Amador, J. A., and Medina, S.: The midsummer drought over Mexico and Central America, J. Climate, 12, 1577 1588, 1999.

McArthur, L. J. B., Fioletov, V. E., Kerr, J. B., McElroy, C. T., and Wardle, D. I.: Derivation of UV-A irradiance from pyranometer measurements, J. Geophys. Res., 104, 30139-30151, doi:10.1029/1999JD900808, 1999.

Molina, L. T. and Molina, M. J.: Improving air quality in megacities: Mexico City case study, Ann. NY Acad. Sci., 1023, 142-158, 2004.

Molina, L. T., Madronich, S., Gaffney, J. S., Apel, E., de Foy, B., Fast, J., Ferrare, R., Herndon, S., Jimenez, J. L., Lamb, B., Osornio-Vargas, A. R., Russell, P., Schauer, J. J., Stevens, P. S., Volkamer, R., and Zavala, M.: An overview of the MILAGRO 2006 Campaign: Mexico City emissions and their trans- 
port and transformation, Atmos. Chem. Phys., 10, 8697-8760, doi:10.5194/acp-10-8697-2010, 2010.

Nickerson, C. E., Sosa, G., Hochstein, H., MacCaslin, P., Luke, W., and Schanot, A.: Measurements of Mexico City air pollution by a research aircraft, Atmos. Environ., 26B, 445-451, 1992.

Perez Vidal, H. and Raga, G. B.: On the vertical distribution of pollutants in Mexico City, Atmósfera, 11, 95-108, 1998.

Raga, G. B. and Le Moyne, L.: On the nature of air pollution dynamics in Mexico City - I. Nonlinear analysis, Atmos. Environ., 30, 3987-3993, 1996.

Raga, G. B., Baumgardner, D., Castro, T., Martinez-Arroyo, A., and Navarro-Gonzalez, R.: Mexico City air quality: A qualitative review of gas and aerosol measurements (1960-2000), Atmos. Environ., 35, 4041-4058, 2001.

Riley, E. M., Mapes, B. E., and Tulich, S. N.: Clouds associated with the Madden-Julian Oscillation: a new perspective from CloudSat, J. Atmos. Sci., 68, 3032-3061, 2011.

Rodríguez, S., Huerta, G., and Reyes, H.: A study of trends for Mexico City ozone extremes: 2001-2014, Atmósfera, 29, 107-120, 2016.

Smith, A., Lott, N., and Vose, R.: The Integrated Surface Database: Recent Developments and Partnerships, B. Am. Meteorol. Soc, 92, 704-708, 2011.

Stephens, S., Madronich, S., Wu, F., Olson, J. B., Ramos, R., Retama, A., and Muñoz, R.: Weekly patterns of México City's surface concentrations of $\mathrm{CO}, \mathrm{NO}_{x}, \mathrm{PM}_{10}$ and $\mathrm{O}_{3}$ during 19862007, Atmos. Chem. Phys., 8, 5313-5325, doi:10.5194/acp-85313-2008, 2008.

Thompson, A. M., Yorks, J. E., Miller, S. K., Witte, J. C., Dougherty, K. M., Morris, G. A., Baumgardner, D., Ladino, L., and Rappenglück, B.: Tropospheric ozone sources and wave activity over Mexico City and Houston during MILAGRO/Intercontinental Transport Experiment (INTEX-B) Ozonesonde Network Study, 2006 (IONS-06), Atmos. Chem. Phys., 8, 5113-5125, doi:10.5194/acp-8-5113-2008, 2008.
Wheeler, M. and Hendon, H.: An all-season real-time multivariate MJO index: Development of an index for monitoring and prediction, Mon. Weather Rev., 132, 1917-1932, 2004.

Whiteman, C. D., Zhong, S., Bian, X., Fast, J. D., and Doran, J. C.: Boundary layer evolution and regional-scale diurnal circulations over the Mexico Basin and Mexican Plateau, J. Geophys. Res., 105, 10081-10102, 2000.

WHO: Health risks of ozone from long-range transboundary air pollution, World Health Organization, available at: http://www.euro. who.int/_data/assets/pdf_file/0005/78647/E91843.pdf (last access: May 2016), 2008.

Wilks, D.: Statistical Methods in the Atmospheric Sciences, 3rd ed., Academic Press, USA, 704 pp., 2011.

Wu, M.-L. C., Schubert, S. D., Suarez, M. J., Pegion, P. J., and Waliser, D. E.: Seasonality and meridional propagation of the MJO, J. Climate, 19, 1901-1921, 2006.

Zhang, C.: Madden-Julian Oscillation, Rev. Geophys., 43, 1-36, 2005.

Zhang, C. and Dong, M.: Seasonality in the Madden-Julian Oscillation, J. Climate, 17, 3169-3180, 2004.

Zhang, Y., Dubey, M. K., Olsen, S. C., Zheng, J., and Zhang, R.: Comparisons of WRF/Chem simulations in Mexico City with ground-based RAMA measurements during the 2006-MILAGRO, Atmos. Chem. Phys., 9, 3777-3798, doi:10.5194/acp-9-3777-2009, 2009. 